\title{
Multivariate Analyses of Potentially Toxic Elements along an Industrialized Urban River in Northern Taiwan
}

\author{
Kuo-Yen Wei ${ }^{*}{ }^{(0)}$, Li-Chuan Hsu Huang2, Chuen-Lan Yen ${ }^{3}$ \\ ${ }^{1}$ Research Center for Future Earth, NTU, Taiwan \\ ${ }^{2}$ Industrial Technology Research Institute, Taiwan \\ ${ }^{3}$ Environmental Analysis Laboratory, EPA, Taiwan \\ Email: *weiky@ntu.edu.tw
}

How to cite this paper: Wei, K.-Y., Huang, L.-C.H. and Yen, C.-L. (2021) Multivariate Analyses of Potentially Toxic Elements along an Industrialized Urban River in Northern Taiwan. Journal of Environmental Protection, 12, 983-1000.

https://doi.org/10.4236/jep.2021.1211057

Received: September 9, 2021

Accepted: November 27, 2021

Published: November 30, 2021

Copyright (c) 2021 by author(s) and Scientific Research Publishing Inc. This work is licensed under the Creative Commons Attribution International License (CC BY 4.0).

http://creativecommons.org/licenses/by/4.0/

\begin{abstract}
The Ker-Ya River flows through the high-tech industrial park and urban residential areas of Hsin-Chu in northern Taiwan. Major and trace element concentrations of waste effluents, river water, and sediment samples collected during 2017 along the Ker-Ya River were analyzed to elucidate the distribution pattern of potential pollutants. Principal component analyses were applied, and four major contaminant associations were recognized: 1) Ce, Co, $\mathrm{Fe}, \mathrm{La}, \mathrm{V}$, and $\mathrm{Cr}$; 2) $\mathrm{Cu}$ and $\mathrm{Ni}$ associated with $\mathrm{Hg}, \mathrm{Ni}, \mathrm{P}, \mathrm{Ga}, \mathrm{W}$, In, and $\mathrm{Ti}$; 3) $\mathrm{B}, \mathrm{Li}, \mathrm{Ba}, \mathrm{Ca}$, and $\mathrm{Ag}$; and 4) Sn with $\mathrm{Zn}$, In, and $\mathrm{Cd}$. All associations are considered to be mainly anthropogenic. Although the element associations recognized from the water samples are not exactly the same as those from the sediment samples but nevertheless, they are similar, suggesting that the short-term and long-term distribution patterns are consistent. The A association accounts for the most variance in the data and exhibits the widest distribution, suggesting the existence of contaminant sources in the upper and lower reaches, respectively. The sediments near the outlet of the city sewage plant also contain association A elements, signaling incomplete processing of the diverged waters sent to the plant at the river mouth. The B association (mainly $\mathrm{Cu}$ and $\mathrm{Ni}$ ) appeared mainly in the upper and middle reaches, indicative of sources from industries in the upper reaches and the tributary Nan-Men Creek. The C association (B, Ba, Ca, and Li) was limited to the center part of the river, probably attributable to a nearby paper mill. The $\mathrm{D}$ association (primarily $\mathrm{Sn}, \mathrm{In}$, and $\mathrm{Zn}$ ) was present in the top point of the middle reaches, suggesting the presence of other contaminant sources in the upper reaches. Although a total of four concomitant associations were recognized, none of the elements exceeded the drinking water standard, suggesting that there was no severe pollution present.
\end{abstract}




\section{Keywords}

Toxic Elements, Spatial Distribution, Principal Component Analysis, Point Sources

\section{Introduction}

Despite efforts advanced in sewage treatment, monitoring and law enforcement, pollution caused by wastewaters discharged from domestic, agriculture, and industry remains a dire and challenging problem in many cities [1]-[9]. This is also the case in certain cities in Taiwan [10] [11]. This paper uses a multivariate statistical method to investigate the element data of river water and surface sediment samples to determine contaminant distribution patterns and elucidate possible pollution sources in a densely populated, highly industrialized area, Hsin-Chu, in northern Taiwan.

Hsin-Chu has been developed as a major high-tech industrial area since 1980, and the related information technology (IT) industrial complex, also known as "Eastern Silicon Valley", is clustered in the Hsinchu Science Park (HSP) and its environs. The Ker-Ya River is the single major river flowing through the industrialized urban complex. In the watershed, there exist more than 500 manufacturing factors, including plants of electroplating, computer chip manufacturing, packaging assembly, rubber processing, paper and pulp mills, glass factories, chemical plants, cement factories, biotechnology companies, fertilizer manufacturing, printing, dyeing, and metal processing. Indeed, more than 400 plants are located inside of the HSP, located to the north of the Ker-Ya River in its middle reaches. Along the upper reaches remain farms, possibly discharging agricultural wastes too.

Ever since the establishment of the HSP in 1980, waste management, regular monitoring, and law enforcement have been implemented. Yet, several major environmental events occurred in the late 1990s, including the pungent smell of the river water, abnormal statistics of blood test results of inhabitants in neighboring communities, and repetitive dead fish incidents in the Ker-Ya River [12], [13]. Currently, the Ker-Ya River itself is still the major receiving water body in the city of different kinds of contaminants discharged from various sources, including agricultural wastewater in the upper reaches, industrial and municipal runoff from the middle and lower reaches in the downtown area, and probably occasional illegal dumping of untreated wastewater from dispersed industries. Among the numerous pollutants, anthropogenic metals are highly mobile and bioavailable, and therefore can impart adverse effects on aquatic biota and human beings [14] [15].

Beginning from 2015, as a measure designed to improve the water quality of the Ker-Ya River running through the urban area of Hsin-Chu, the waters of small tributary creeks were intercepted at four sites before they enter the main 
course of the Ker-Ya River. These waters have been sent via sub-ground conduits to a sewage plant located near the river mouth. The interception and processing have improved the river water quality significantly in the downtown area, as evidenced by the marked reduction of bulk organic deposits (BOD) from $9.0 \mathrm{mg} / \mathrm{L}$ to $6.6 \mathrm{mg} / \mathrm{L}$. Nevertheless, a previous general survey of the sediments in the wetland and water mouth area during 2012-2016 by the Taiwan Environment Protection Administration (TEPA) showed that the concentrations of As, $\mathrm{Cu}, \mathrm{Hg}, \mathrm{Ni}$, and $\mathrm{Zn}$ occasionally exceeded the lower limit of sediment quality prescribed by TEPA. Monitoring of the river water quality also identified relatively high concentrations of $\mathrm{Pb}, \mathrm{As}, \mathrm{Cu}, \mathrm{Zn}$, and $\mathrm{Mn}$ during 2016, although only Mn $(0.234 \mathrm{mg} / \mathrm{L})$ exceeded the quality standard value (not potable). All of these alarming findings called for a thorough study of the distribution of contaminants in the watershed of the Ker-Ya River. The present research investigated a total of 67 species of inorganic contaminants, which is far beyond the conventional nine elements $(\mathrm{Cd}, \mathrm{Pb}, \mathrm{Cr}, \mathrm{As}, \mathrm{Hg}, \mathrm{Cu}, \mathrm{Zn}, \mathrm{Mn}$, and $\mathrm{Ag}$ ) required by current legislation in Taiwan. The purpose of such a markedly more comprehensive study is to attempt to recognize potential risks associated with new trace metals recently used in high-tech manufacturing and to identify other potential sources of pollutants.

This paper aims to examine the distribution patterns of major and trace elements measured from water and surface sediment samples in three batches collected during 2017 along the Ker-Ya River using multivariate analysis. The main purpose was to reveal the inter-relationship of various elements, and thus elucidate possible pollutant sources, as well as to map the distribution of such potential pollutants along the urban waterways in Hsin-Chu. The obtained results can shed new light on environmental forensics and contribute to optimal environment governance.

\section{Materials and Methods}

\section{Study Area and Sampling Design}

The Ker-Ya River originates from the hilly Bao-Shan County to the east of the city at approximately a 100-m high altitude. It flows westerly through Hsin-Chu and enters the Taiwan Strait via a $24-\mathrm{km}$ journey with a watershed of approximately 4560 ha. The upper reaches supply agriculture usage water, while the middle and lower reaches flow through the urban areas with a dense population (Figure 1). Geologically, the upper reaches eroded and carry sediments from Pliocene sandstone and mudstone, Quaternary table-land conglomerates, and alluvial deposits in the middle and lower reaches. The annual discharge of the Ker-Ya River is approximately $7830 \mathrm{~km}^{3}$, exhibiting a mild seasonal fluctuation with relatively high discharge during May - September. According to the permit registration of the Taiwan Environment Protection Administration (TEPA), the major sources of processed water discharges are the Hsinchu Science Park (HSP) $\left(104,842 \mathrm{~m}^{3} / \mathrm{d}\right)$, Paper Mill A $\left(2132 \mathrm{~m}^{3} / \mathrm{d}\right)$, and Glass Factory B $\left(172 \mathrm{~m}^{3} / \mathrm{d}\right)$ 


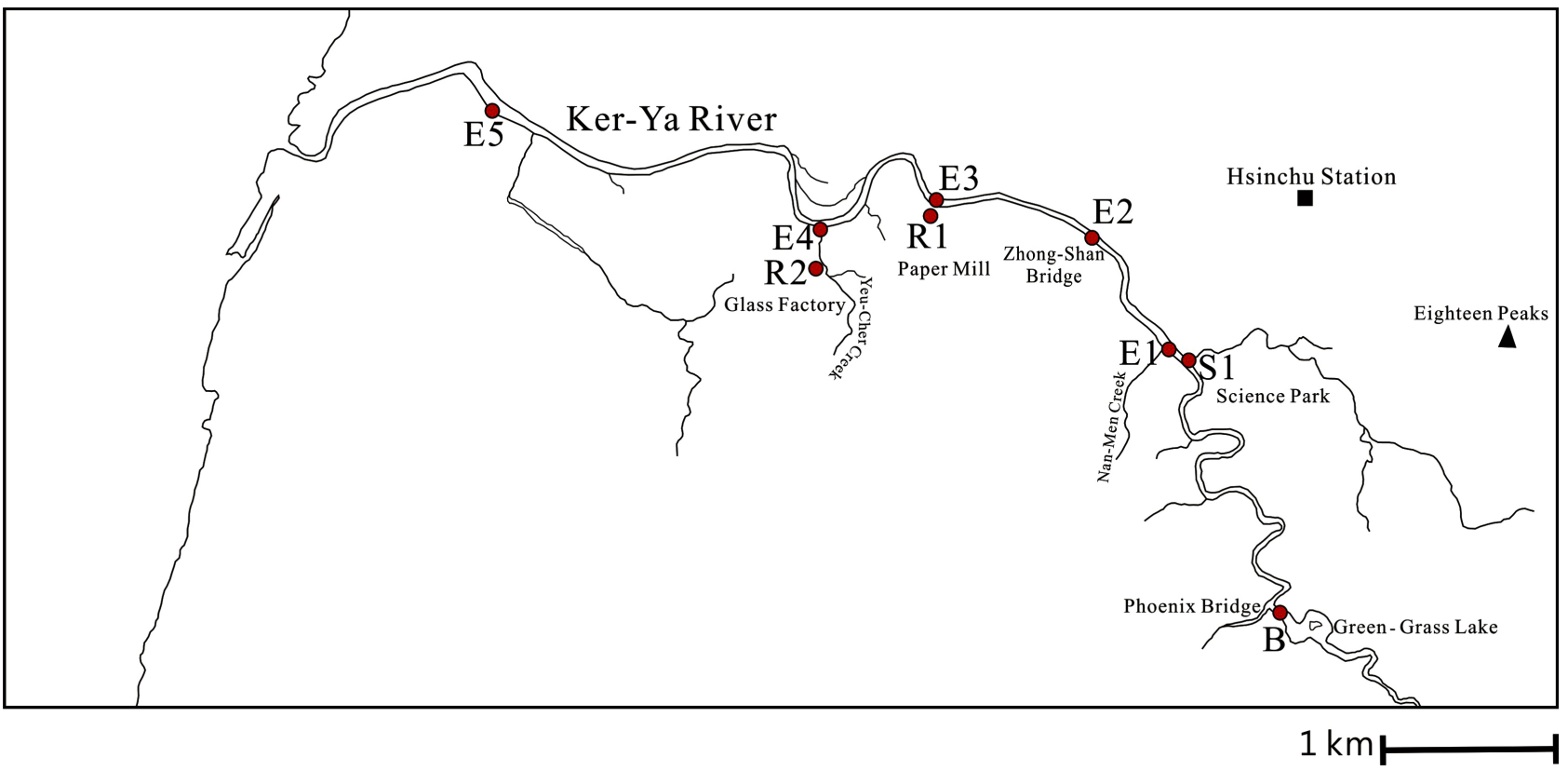

Figure 1. Location map of sampling sites (red dots) in the 2017 studied area along the middle and lower reaches of the Ker-Ya River, Hsinchu, northern Taiwan.

(see Figure 1 for their locations).

Sampling points at 19 nodes along the Ker-Ya River were strategically chosen, mainly at the outlets of plants and confluence points of the river and creeks. A total of 35 water samples were collected in three batches on June 26-27, August 21-22, and October 10-12, respectively, during 2017. Meanwhile, a total of 20 surface sediment samples were taken at the same location or in the neighborhood of the water samples. Sample ID, collection dates, and coordinates of these samples are listed in Table 1 . All of the sampling methods followed the procedures described in NIEA W102.51C (2005) and NIEA S104.32B (2016) issued by TEPA. Briefly, about $1 \mathrm{~L}$ river water was sampled in situ and $\mathrm{HNO}_{3}$ solution was added immediately to make the $\mathrm{PH}<2$, stored at $4^{\circ} \mathrm{C}$ for further analyses. About 250 gm surface sediments (sub-depth $1-15 \mathrm{~cm}$ ) were taken using an Ekman dredge, and then immediately stored in plastic bags and refrigerated at $4^{\circ} \mathrm{C}$. All the NIEA guidelines (in Chinese) can be found on Internet Web.

A total of 67 major and trace metals were measured. Analytical methods followed the guideline NIEA M353.02C (2016) prescribed by TEPA. Briefly, water and sediment samples were first filtered through $0.45 \mu \mathrm{m}$ pore-size membrane filter paper (Whatman $5 \mathrm{~A}$ ), and then the filtered samples were put in $\mathrm{H}_{2} \mathrm{O}_{2}(30 \%$, Suprapure, Merck) and $\mathrm{HNO}_{3}$ solution (65\%, Suprapure, Merck) with $\mathrm{pH}<2$ to convert the dissolved metal ions into nitrates. The nitrates were subsequently analyzed with inductively coupled plasma mass spectrometer (ICP/MS, Agilent 7500S) (following NIEA M353.02C, 2016).

Only concentrations of 46 elements (Ag, As, Au, B, Ba, Bi, Br, Ca, Cd, Ce, Co, $\mathrm{Cr}, \mathrm{Cs}, \mathrm{Cu}, \mathrm{Fe}, \mathrm{Ga}, \mathrm{Ge}, \mathrm{Hf}, \mathrm{Hg}$, I, In, K, La, Li, Mg, Mo, Nd, Ni, P, Pb, Pr, Rb, Sb, Sc, Si, Sm, Sn, Sr, Th, Ti, U, V, W, Y, Zn, and Zr) were reported and for statistical 
Table 1. Sample list in the watershed of the Ker-Ya River.

\begin{tabular}{|c|c|c|c|c|c|}
\hline ID & location & date & longitude & latitude & type \\
\hline KYW01 & Outlet of Paper Plant A (S3) & $2017 / 6 / 26$ & 120.946336 & 24.801126 & water \\
\hline KYW02 & Outlet of Paper Plant A (S3) & $2017 / 8 / 22$ & 120.946336 & 24.801126 & water \\
\hline KYW03 & Outlet of Paper Plant A (S3) & $2017 / 10 / 12$ & 120.946336 & 24.801126 & water \\
\hline KYW04 & Original Waste Water of Paper Plant A (R1) & $2017 / 6 / 26$ & 120.946602 & 24.801186 & water \\
\hline KYW05 & Original Waste Water of Paper Plant A (R1) & $2017 / 8 / 22$ & 120.946602 & 24.801186 & water \\
\hline KYW06 & Original Waste Water of Paper Plant A (R1) & $2017 / 10 / 12$ & 120.946602 & 24.801186 & water \\
\hline KYW07 & Phoenix Bridge (B) & $2017 / 6 / 26$ & 120.946602 & 24.801186 & water \\
\hline KYW08 & Confluence of Paper Plant A Outlet (E3) & $2017 / 6 / 26$ & 120.946602 & 24.801186 & water \\
\hline KYW09 & Urban effluence at Zhong-Shan Bridge (S2) & $2017 / 6 / 27$ & 120.946602 & 24.801186 & water \\
\hline KYW10 & Urban effluence at Zhong-Shan Bridge (S2) & $2017 / 8 / 21$ & 120.946336 & 24.801126 & water \\
\hline KYW11 & Confluence of Yeo-Che Creek (E4) & $2017 / 6 / 27$ & 120.946336 & 24.801126 & water \\
\hline KYW12 & Confluence of Science Park Outlet (S1) & $2017 / 6 / 27$ & 120.946336 & 24.801126 & water \\
\hline KYW13 & Confluence of Nan-Men Creek (E1) & $2017 / 6 / 27$ & 120.937817 & 24.799799 & water \\
\hline KYW14 & Phoenix Bridge (B) & $2017 / 8 / 21$ & 120.937817 & 24.799799 & water \\
\hline KYW15 & Confluence of Science Park Outlet (S1) & $2017 / 8 / 21$ & 120.937817 & 24.799799 & water \\
\hline KYW16 & Confluence of Nan-Men Creek (E1) & $2017 / 8 / 21$ & 120.937817 & 24.799799 & water \\
\hline KYW17 & Zhong-Shan Bridge (E2) & $2017 / 6 / 26$ & 120.937817 & 24.799799 & water \\
\hline KYW18 & Zhong-Shan Bridge (E2) & $2017 / 8 / 21$ & 120.937817 & 24.799799 & water \\
\hline KYW19 & Urban effluence at Zhong-Shan Bridge (S2) & $2017 / 10 / 11$ & 120.969668 & 24.775633 & water \\
\hline KYW20 & Outlet of Glass Plant B (S4) & $2017 / 6 / 27$ & 120.969668 & 24.775633 & water \\
\hline KYW21 & Confluence of Paper Plant A Outlet (E3) & $2017 / 8 / 22$ & 120.969668 & 24.775633 & water \\
\hline KYW22 & Confluence of Yeo-Che Creek (E4) & $2017 / 8 / 22$ & 120.962542 & 24.792123 & water \\
\hline KYW23 & River Mouth (E5) & $2017 / 8 / 23$ & 120.962542 & 24.792123 & water \\
\hline KYW24 & Phoenix Bridge (B) & $2017 / 10 / 11$ & 120.962542 & 24.792123 & water \\
\hline KYW25 & Confluence of Science Park Outlet (S1) & $2017 / 10 / 11$ & 120.962542 & 24.792123 & water \\
\hline KYW26 & Confluence of Nan-Men Creek (E1) & $2017 / 10 / 11$ & 120.962542 & 24.792123 & water \\
\hline KYW27 & Zhong-Shan Bridge (E2) & $2017 / 10 / 11$ & 120.962542 & 24.792123 & water \\
\hline KYW28 & Outlet of Glass Plant B (S4) & $2017 / 8 / 22$ & 120.957347 & 24.799439 & water \\
\hline KYW29 & Outlet of Glass Plant B (S4) & $2017 / 10 / 12$ & 120.957347 & 24.799439 & water \\
\hline KYW30 & Outlet of Glass Plant B (S4) & $2017 / 6 / 27$ & 120.957347 & 24.799439 & water \\
\hline KYW31 & Outlet of Glass Plant B (S4) & $2017 / 8 / 22$ & 120.957347 & 24.799439 & water \\
\hline KYW32 & Original Waste Water of Glass Plant B (R2) & $2017 / 10 / 12$ & 120.957347 & 24.799439 & water \\
\hline KYW33 & Confluence of Paper Plant A Outlet (E3) & $2017 / 10 / 12$ & 120.957347 & 24.799439 & water \\
\hline KYW34 & Confluence of Yeo-Che Creek (E4) & $2017 / 10 / 12$ & 120.957347 & 24.799439 & water \\
\hline KYW35 & River Mouth (E5) & $2017 / 10 / 13$ & 120.957347 & 24.799439 & water \\
\hline KYS01 & Confluence of Paper Plant A Outlet (E3) & $2017 / 6 / 26$ & 120.957347 & 24.799439 & sediment \\
\hline
\end{tabular}




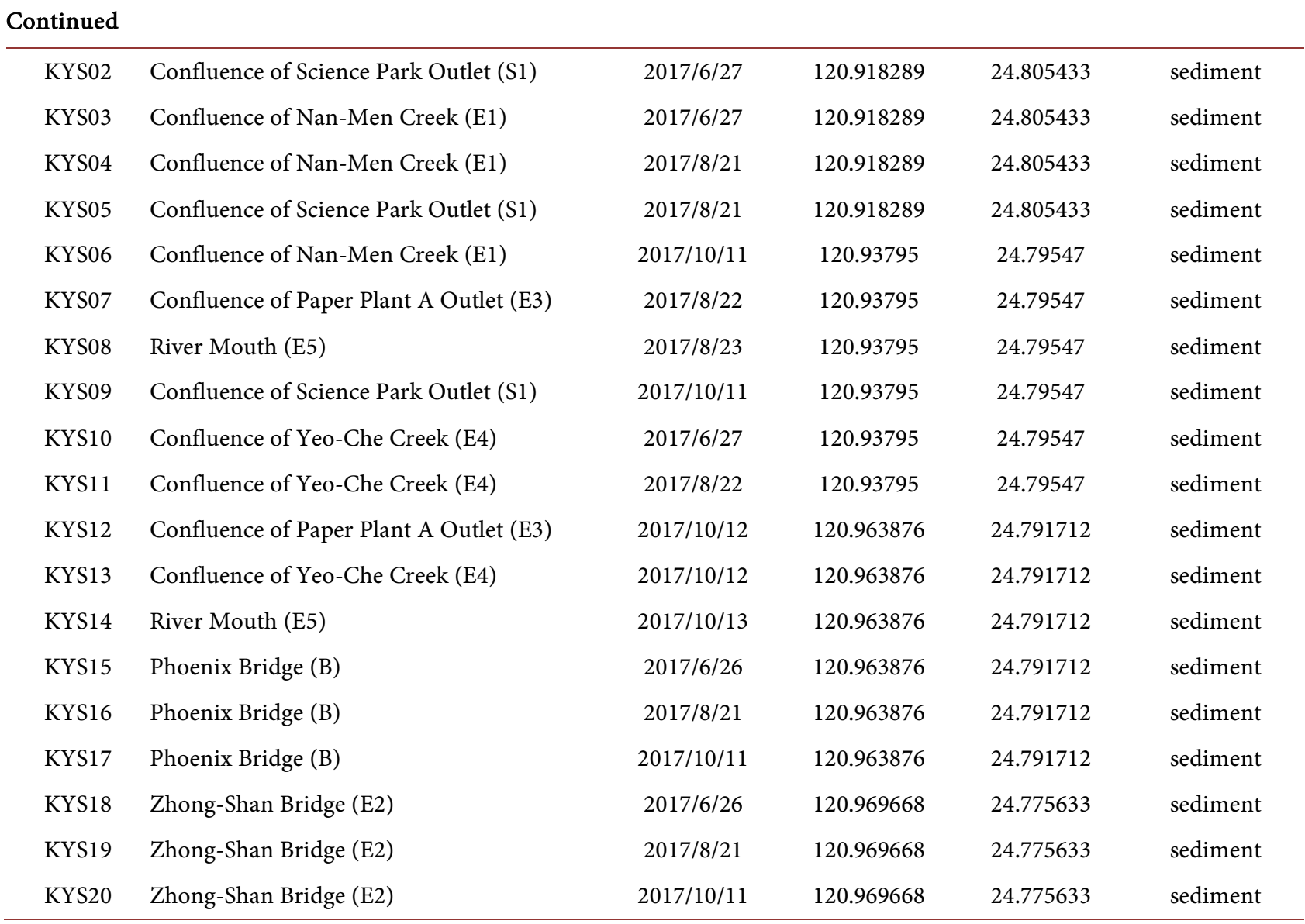

analyses because most of the other elements were usually below the detection limits at the ppb level.

A substantial body of literature has demonstrated that multivariate analyses could easily yield meaningful results in recognizing significant parameters and identifying pollution sources [2] [3] [16]-[22]. The element data of waters and sediments were subjected to a series of principal component analyses (PCA) separately. Mathematically, each principal component (PC) is a linear combination of the original variables, and all the principle components are not correlated with one another. The purposes of PCA are three-fold: 1) reducing the dimensionality, while retaining the most variance in the data with a few principal components (PCs); 2) forming several linear combinations (associations) of individual elements, while the coefficients or correlations of the elements with the PCs are indicative of the relevance among the various elements; and 3) calculating the scores of each sample on the principal components, and thus categorizing the samples into groups in terms of different element associations. Since the concentrations of major and trace elements vary greatly in several orders, in order to avoid the scale effect on the PCA, we used a correlation matrix among the 46 elements initially for preliminary PCA analyses and data evaluation using the software Past 4.02 [23]. Some of the elements that exhibit extremely low concentration and thereby high variability in the correlation matrix were removed from 
analysis because they tended to make particular samples become statistical outliers and to result in spurious PCA solutions. After several runs of iterative PCA analyses, eventually only 24 elements from the water analyses (Table 2) and 25 elements (Table 3 ) from sediments, respectively, were retained for the final eigenfunction and eigenvalue calculation, and the final resolved PCA patterns were eventually stabilized.

Table 2. Correlation coefficients of elements with the first four PCs of the water samples. The second row lists the variance explained by the first four principal components (PCs), respectively. The remaining lines list the correlation coefficients of elements with the four PCs. Significantly high correlation coefficients are marked with bold-face.

\begin{tabular}{|c|c|c|c|c|}
\hline & $\mathrm{PC} 1$ & PC2 & PC3 & PC4 \\
\hline Variance explained & $33.60 \%$ & $19.90 \%$ & $14.10 \%$ & $8.40 \%$ \\
\hline As & 0.45 & 0.76 & 0.03 & -0.01 \\
\hline B & 0.42 & -0.45 & 0.64 & -0.26 \\
\hline $\mathrm{Ba}$ & 0.06 & -0.55 & 0.68 & 0.01 \\
\hline $\mathrm{Ca}$ & 0.58 & 0.03 & 0.62 & -0.45 \\
\hline $\mathrm{Cd}$ & 0.11 & -0.28 & -0.02 & 0.3 \\
\hline $\mathrm{Ce}$ & -0.93 & 0.16 & 0.03 & -0.09 \\
\hline Co & -0.83 & 0.08 & 0.46 & -0.25 \\
\hline $\mathrm{Cr}$ & -0.81 & 0.30 & 0.39 & 0.12 \\
\hline $\mathrm{Cu}$ & 0.31 & 0.90 & 0.13 & 0.11 \\
\hline $\mathrm{Fe}$ & -0.92 & 0.16 & 0.22 & 0.04 \\
\hline $\mathrm{Hg}$ & 0.49 & 0.83 & -0.08 & -0.03 \\
\hline In & 0.22 & 0.06 & 0.34 & 0.77 \\
\hline $\mathrm{La}$ & -0.94 & 0.09 & 0.05 & -0.06 \\
\hline $\mathrm{Li}$ & -0.07 & -0.10 & 0.82 & 0.39 \\
\hline $\mathrm{Mg}$ & 0.72 & -0.35 & 0.36 & 0.33 \\
\hline Mo & 0.78 & 0.04 & 0.54 & 0.11 \\
\hline $\mathrm{Ni}$ & -0.12 & 0.93 & 0.21 & 0.01 \\
\hline $\mathrm{P}$ & 0.45 & 0.87 & -0.02 & -0.01 \\
\hline $\mathrm{Si}$ & 0.87 & 0.24 & 0.17 & 0.27 \\
\hline Sn & 0.20 & -0.18 & 0.22 & 0.79 \\
\hline $\mathrm{Sr}$ & 0.88 & -0.10 & 0.37 & 0.05 \\
\hline $\mathrm{V}$ & -0.94 & 0.19 & 0.23 & -0.02 \\
\hline $\mathrm{W}$ & 0.51 & 0.81 & -0.15 & -0.05 \\
\hline $\mathrm{Zn}$ & -0.06 & -0.15 & 0.04 & 0.45 \\
\hline
\end{tabular}


Table 3. Correlation table of elements with the first four PCs of the sediment samples. The second row lists the variance explained by the first four principal components (PCs), respectively. The remaining lines list the correlation coefficients of elements with these four PCs. Significantly high correlation coefficients are marked with bold-face.

\begin{tabular}{|c|c|c|c|c|}
\hline & PC1 & PC2 & PC3 & PC4 \\
\hline Variance explained & $43.2 \%$ & $20.6 \%$ & $16.7 \%$ & $5.10 \%$ \\
\hline $\mathrm{Ag}$ & 0.30 & -0.60 & 0.69 & 0.1 \\
\hline $\mathrm{B}$ & 0.41 & -0.57 & 0.66 & 0.02 \\
\hline $\mathrm{Ba}$ & -0.24 & -0.42 & 0.81 & 0.02 \\
\hline $\mathrm{Br}$ & 0.90 & 0.26 & 0.11 & -0.12 \\
\hline $\mathrm{Ca}$ & 0.67 & -0.28 & 0.65 & 0.03 \\
\hline $\mathrm{Cd}$ & 0.04 & -0.09 & -0.36 & 0.61 \\
\hline $\mathrm{Ce}$ & -0.84 & 0.28 & 0.14 & -0.34 \\
\hline Co & -0.84 & 0.25 & 0.46 & 0.03 \\
\hline $\mathrm{Cr}$ & -0.76 & 0.48 & 0.29 & 0.23 \\
\hline $\mathrm{Cu}$ & 0.52 & 0.77 & -0.00 & 0.08 \\
\hline $\mathrm{Fe}$ & -0.86 & 0.34 & 0.23 & 0.2 \\
\hline $\mathrm{Ga}$ & -0.09 & 0.80 & 0.40 & 0.02 \\
\hline $\mathrm{Hg}$ & 0.81 & 0.49 & -0.10 & -0.18 \\
\hline In & 0.31 & 0.77 & 0.06 & 0.22 \\
\hline K & 0.85 & 0.44 & 0.01 & -0.08 \\
\hline $\mathrm{La}$ & -0.87 & 0.21 & 0.15 & -0.34 \\
\hline $\mathrm{Li}$ & 0.06 & 0.04 & 0.91 & 0.16 \\
\hline $\mathrm{Mg}$ & 0.87 & -0.21 & 0.37 & -0.01 \\
\hline Mo & 0.87 & 0.16 & 0.44 & 0.07 \\
\hline $\mathrm{Ni}$ & 0.34 & 0.88 & 0.16 & 0.07 \\
\hline $\mathrm{Si}$ & 0.95 & 0.14 & 0.08 & 0.07 \\
\hline $\mathrm{Sr}$ & 0.85 & -0.28 & 0.42 & 0.02 \\
\hline $\mathrm{Ti}$ & 0.43 & 0.75 & 0.05 & 0.08 \\
\hline $\mathrm{V}$ & -0.87 & 0.38 & 0.28 & -0.04 \\
\hline $\mathrm{Zn}$ & 0.28 & 0.29 & 0.22 & 0.76 \\
\hline
\end{tabular}

\section{Results and Discussion}

\subsection{PCA Results of Water Samples}

A scree plot of the variance associated with each principal component of the water samples shows that starting from the principal component 5 and the succeeding ones account for only incrementally small amounts, and therefore only 
the first four principal components were retained for further interpretation. In total, these four principal components (PCs) account for $76 \%$ of the variance (Table 2). Four major contaminant associations were recognized accordingly: 1) $\mathrm{V}, \mathrm{La}, \mathrm{Ce}, \mathrm{Fe}, \mathrm{Co}, \mathrm{Cr}$, and $\mathrm{La}$ with significant negative correlation coefficients with PC1; 2) As, $\mathrm{Cu}, \mathrm{Hg}, \mathrm{Ni}, \mathrm{P}$, and $\mathrm{W}$ with high correlation with PC2; 3) B, Ba, $\mathrm{Ca}$, and Li with high correlation with PC3; and 4) In, Sn, and Zn, with high correlation with PC4. The listed elements in the four associations are mainly characteristic of anthropogenic origin.

\subsection{PCA Results of Sediment Samples}

Four PCs were retained for the sediment samples, accounting for $85.6 \%$ of the variance in total (Table 3). Corresponding to PC1 - PC4, four-element assemblages were recognized: 1) $\mathrm{Ce}, \mathrm{Co}, \mathrm{Fe}, \mathrm{La}$, and $\mathrm{V}$; 2) $\mathrm{Cu}, \mathrm{Ga}, \mathrm{In}, \mathrm{Ni}$, and $\mathrm{Ti}$; 3$) \mathrm{Ag}$, $\mathrm{B}, \mathrm{Ba}, \mathrm{Ca}$, and $\mathrm{Li}$; and 4) $\mathrm{Cd}$ and $\mathrm{Sn}$. It is expected that the associations recognized from sediments do not necessarily correspond to the overlying water because potentially toxic elements in the Ke-Ya River are mainly bounded with fine-sized $(<25 \mu \mathrm{m})$ sediments, and each element has its own speciation pattern; in general, potentially toxic elements are preferentially bonded with organic matters [9] [15]. Generally, the water samples constitute a snap-shot of chemicals in the water, while surface sediments retain longer-term records.

\subsection{Integrative Interpretations of PCs}

For a thorough interpretation of the PCA results of both water and sediment samples, we discuss contaminant associations one-by-one below. The scatter plots showing the scores of water and sediments are presented in juxtaposition. Table 4 summaries the integrative results in listing samples that have extreme (positive or negative) scores in both water and sediment samples. The locations of the listed samples are presented in a simplified flow chart in Figure 2.

\subsection{Contaminant Association A-PC1}

In the water sample set, the elements with high positive correlation coefficients $(r>0.7)$ with PC1 are considered to be general, background ones, likely to be the crust origin ( $\mathrm{Mg}, \mathrm{Mo}, \mathrm{Si}$, and $\mathrm{Sr}$ ), whereas, the elements with significantly high negative loadings ( $\mathrm{V}, \mathrm{La}, \mathrm{Ce}, \mathrm{Fe}, \mathrm{Co}, \mathrm{Cr}$, and $\mathrm{La}$ ) constitute a contrast against the general background elements, and represent potential pollutants.

Association $\mathrm{A}$ is the most significant contaminant association in the water samples of the Ker-Ya River. These contaminant elements appear in the original effluents of Glass Factory B in the lower reaches area (Figures 1-3). Not surprisingly, these elements are also present in the sediment samples at the confluence of the Yeu-Che Creek where the outlet of the Glass Factory flows in (Figure 1, Figure 2, Figure 4, and Table 4). Nevertheless, these elements also occurred in the water samples of upper reaches, including W07 at the Phoenix Bridge, W13 at the confluence of Nan-Men (South Gate) Creek, and in the urban effluent 
Table 4. Samples with relatively high concentrations in the four contaminant associations recognized by principal component analyses in both water and sediment samples of the Ker-Ya River. The elements exhibiting relatively higher correlation coefficients are bold-faced.

\section{Water samples}

PC1 (Ce, Co, Cr, Fe, La, V)

W30 Wastewater of Glass Plant (R2) 06/27

W31 Wastewater of Glass Plant (R2) 08/22

W07 Phoenix Bridge (B) 06/26

W32 Wastewater of Glass Plant (R2) 10/12

W13 Entrance of Nan-Men Creek (E1) 06/27

W19 Urban effluents at Zhong-Shan Bridge (S2) 10/11

PC2 (As, $\mathrm{Cu}, \mathrm{Hg}, \mathrm{Ni}, \mathrm{P}, \mathrm{W}$ )

W27 Zhong-Shan Bridge (E2) 10/11

PC3 (B, Ba, Ca, Li)

W04 Wastewater of Paper Plant (R1) 06/26

W05 Wastewater of Paper Mill (R1) 08/22

PC4 (In, Sn)

W24 Phoenix Bridge (B) 10/11

PC4 (Zn, Cd)

S04 Entrance of Nan-Men Creek (E1) 8/21

\section{Sediment samples}

PC1 (Ce, Co, Cr, Fe, La, V)

S14 River Mouth (E5) 10/13

S04 Entrance of Nan-Men Creek (E1) 08/21
S13 Entrance of Yeu-Che Creek (E4) 10/12
PC2 (Br, Cu, Ga, In, Ni, Ti)

S17 Phoenix Bridge (B) 10/11

S07 Entrance of Paper Mill effluences (E3) 8/22
PC3 (Ag, B, Ba, Ca, Li)

W25 Entrance of Science Park effluents (S1) 10/11

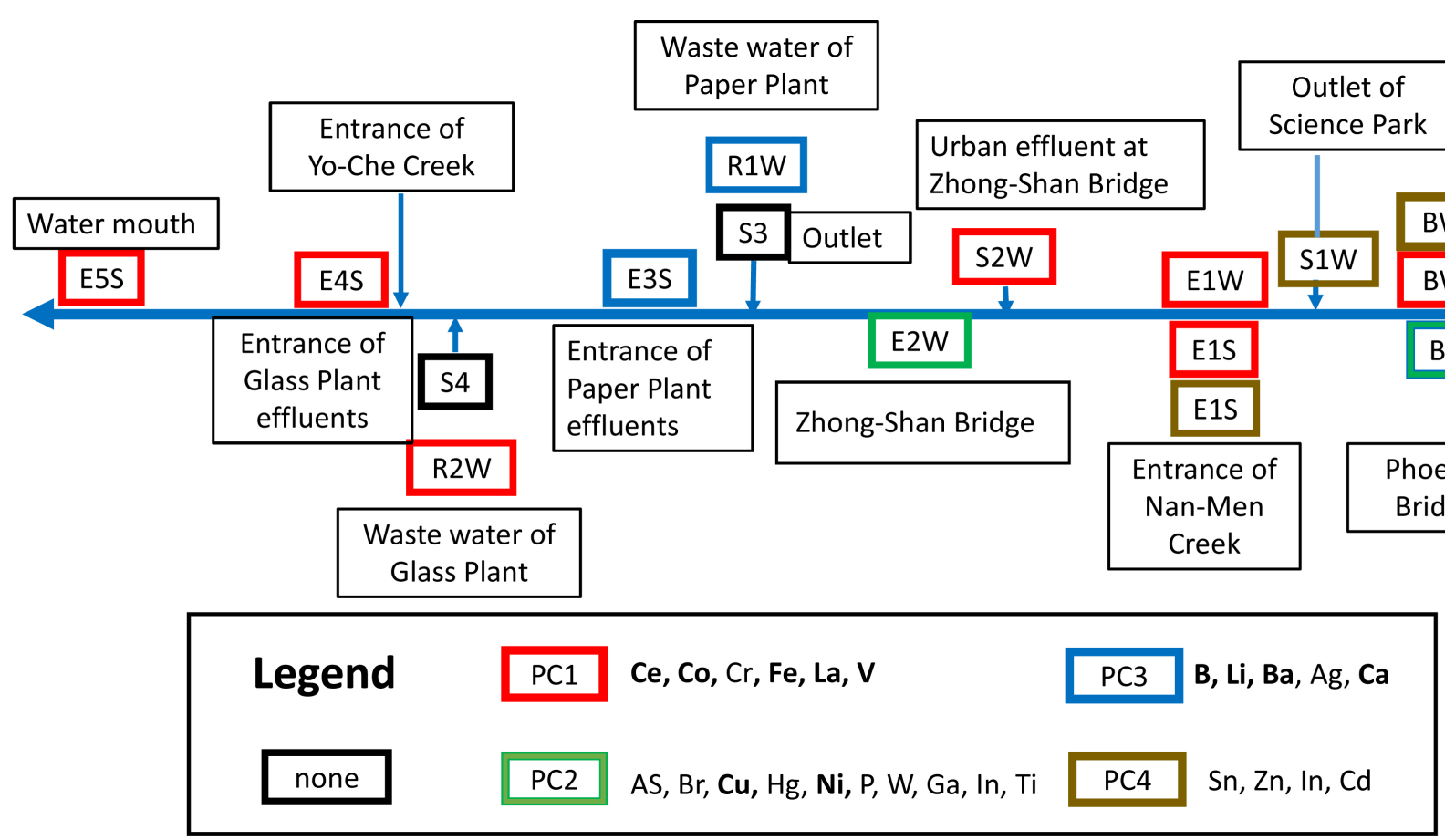

Figure 2. Simplified flow chart showing sample sites and PC1 - PC4 contaminant associations coded in color along the Ker-Ya River. The letter $\mathrm{W}$ in the rectangle indicates water samples, while $\mathrm{S}$ denotes sediment samples. In each associations, the common elements in both water and sediments are bold-faced. It is worth noting that the associations recognized from water samples do not necessarily correspond to those of surface sediment samples. 


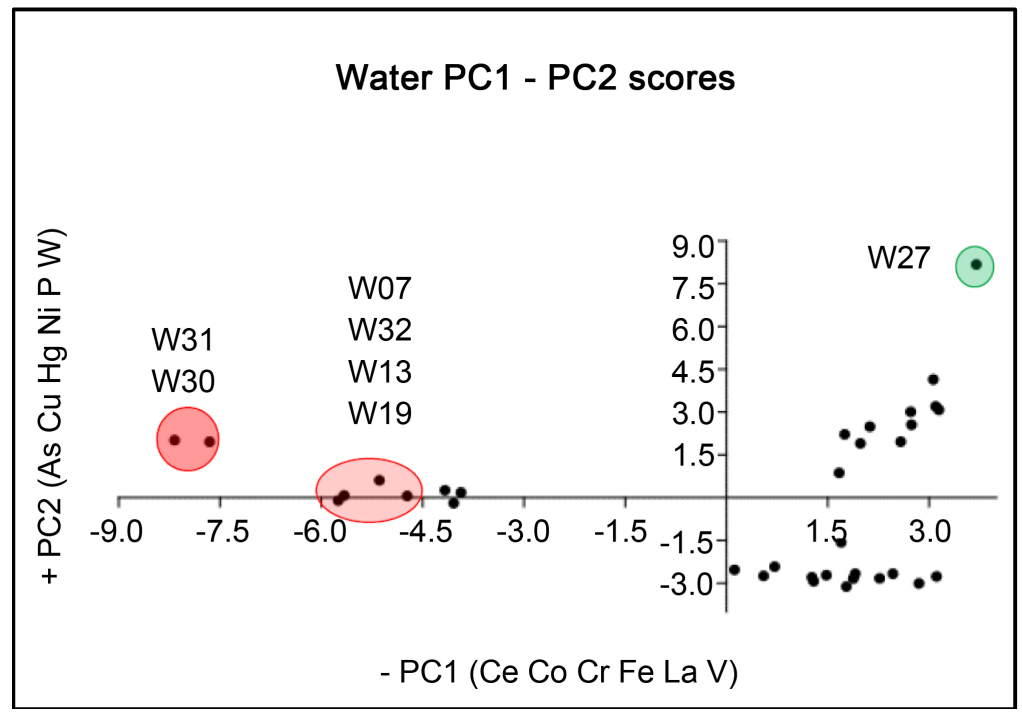

Figure 3. Scatter plot of scores of water samples on the plane of PC1 and PC2. Three groups of water samples containing relatively high concentrations of elements were recognized. The red ellipses mark samples of high concentrations in contaminant association $\mathrm{A}$ ( $\mathrm{PC1}$ : $\mathrm{Ce}, \mathrm{Co}, \mathrm{Cr}, \mathrm{Fe}, \mathrm{La}$, and $\mathrm{V})$, while the green circle marks those of association $\mathrm{B}$ (PC2: $\mathrm{As}, \mathrm{Cu}, \mathrm{Hg}, \mathrm{Ni}, \mathrm{P}$, and W).

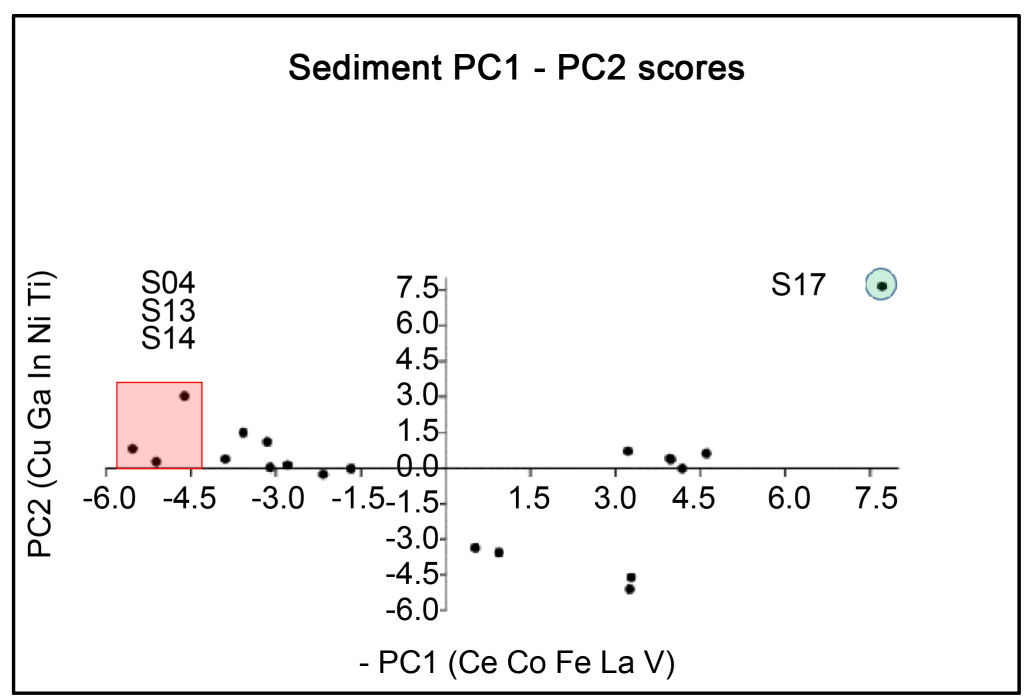

Figure 4. Scatter plot of scores of sediment samples on the plane of PC1 and $\mathrm{PC} 2$. The red rectangle marks samples of high concentrations in association $\mathrm{A}$ (PC1: Ce, Co, Fe, La, and V), while the green circle marks sample S17 with relatively high element concentrations in association $\mathrm{B}(\mathrm{PC} 2 \mathrm{Br}, \mathrm{Cu}, \mathrm{Ga}, \mathrm{Ni}$, and $\mathrm{Ti})$.

discharge into the Ker-Ya River at Zhong-Shan Bridge (Figure 2, Figure 3, and Table 4), suggesting that there were sources in the upper reach and tributary creeks other than Glass Factory B. Consistently, sediment samples also signal the occurrence of association A in S14 (River Mouth), S13 (entrance of Yeu-Che Creek), and S04 (entrance of Nan-Men Creek) (Figure 2, Figure 4, and Table 4). Overall, elements of assemblage A were present in water and surface sedi- 
ments both in the middle and lower reaches.

\subsection{Contaminant Association B-PC2}

The second PC of water samples, accounting for $19.9 \%$ of the variance, is basically an association of $\mathrm{Ni}, \mathrm{Cu}, \mathrm{P}, \mathrm{Hg}, \mathrm{W}$, and $\mathrm{As}$ (in descending order of correlation coefficients, see Table 2). Only one water sample (W27 collected on 2017/10/11 at Zhong-Shan Bridge, Figure 3) contains a high concentration of these elements (Table 2, Figure 3). For sediments, association $\mathrm{B}$ is characterized by $\mathrm{Br}, \mathrm{Cu}, \mathrm{Ga}, \mathrm{In}, \mathrm{Ni}$, and $\mathrm{Ti}$ (Table 4). Only $\mathrm{Cu}$ and $\mathrm{Ni}$ are common in the contaminant associations of water and sediments (Table 4). W27 (Zhong-Shan Bridge (E2) 10/11) and S17 (Phoenix Bridge (B) 10/11) are the two samples showing high scores (Figure 3 and Figure 4).

\subsection{Contaminant Association C-PC3}

The third PC represents an association of $\mathrm{Li}, \mathrm{Ba}, \mathrm{B}$, and $\mathrm{Ca}$ (Tables 2-4) for both water and sediment sets. These elements are characteristic of the original waste water (W4, W5) of the Paper Mill (Figure 5). They were also present in the surface sediment S07 at the entrance of Paper Mill effluences (Figure 6). We consider that this association of elements is closely related to the Paper Mill (Table $4)$.

\subsection{Contaminant Association D-PC4}

The PC4 recognized from water samples has a high correlation with In and Sn, but the sediment's PC4 is correlated mainly with $\mathrm{Zn}$ and Cd (Table 4). According to the loading matrices, PC4 is not a well-defined association, and is only roughly correlated with $\mathrm{Zn}, \mathrm{Cd}$, In, and $\mathrm{Sn}$. Those elements occurred primarily

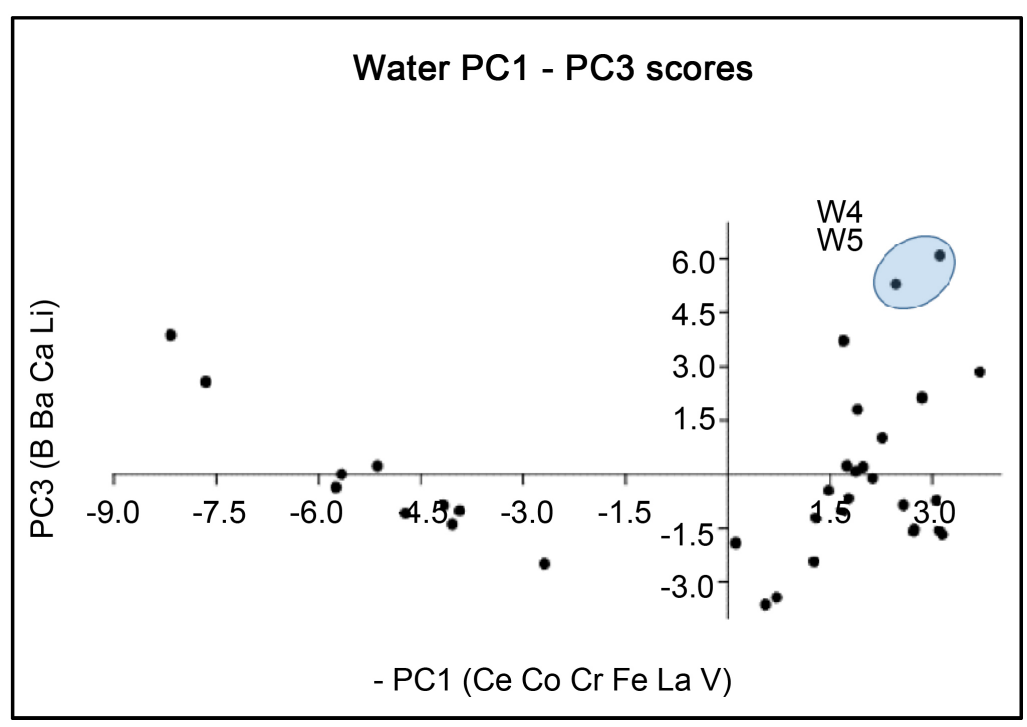

Figure 5. Scatter plot of scores of water samples on the plane of PC1 and PC3. The blue ellipse marks samples of high concentrations in contaminant association $\mathrm{C}$ (PC3: $\mathrm{B}, \mathrm{Ba}, \mathrm{Ca}$, and $\mathrm{Li})$. 


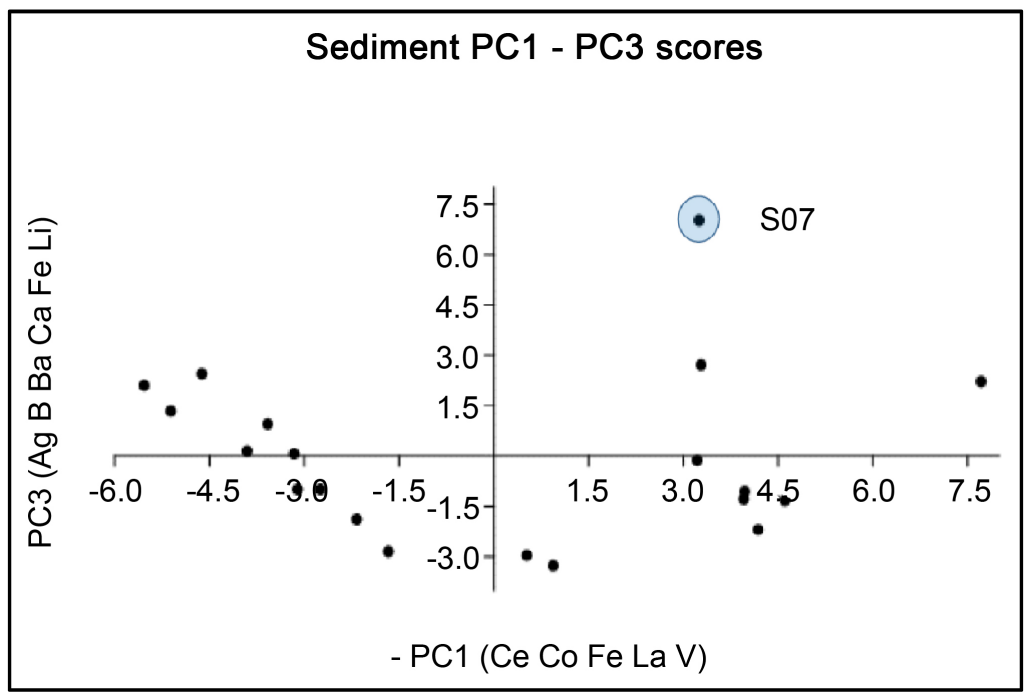

Figure 6. Scatter plot of scores of sediment samples on the plane of PC1 and PC3. The blue circle marks sample S07 which has high concentrations in contaminant association C (PC3: Ag, B, Ba, Ca, and Li).

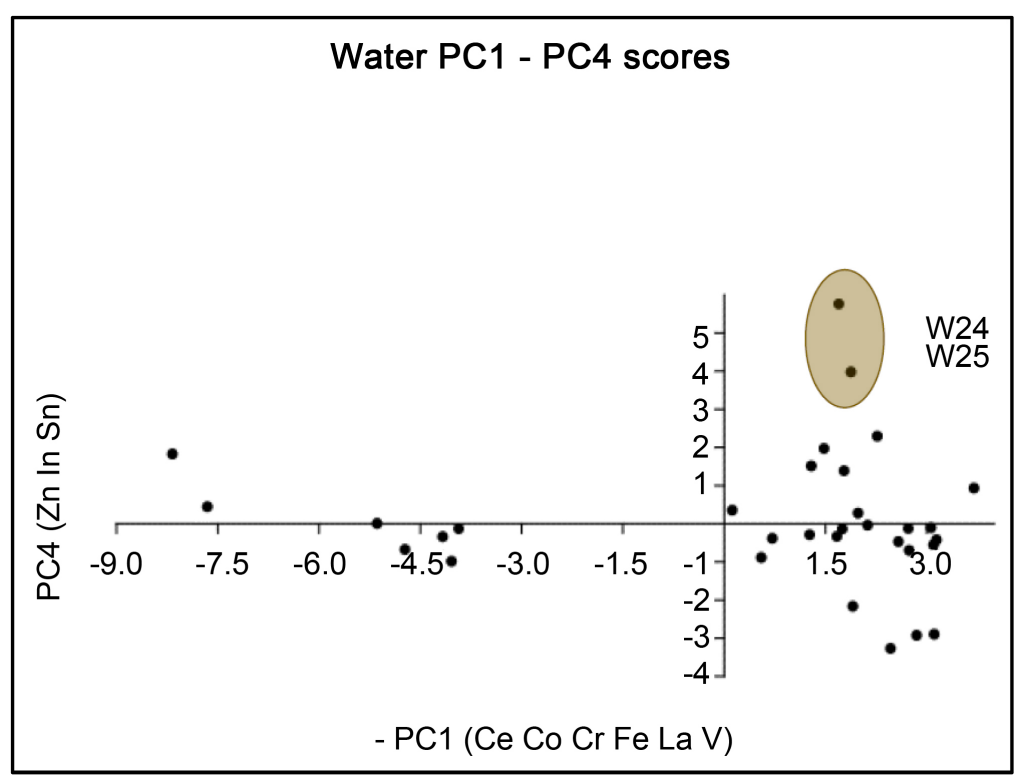

Figure 7. Scatter plot of scores of water samples on the plane of PC1 and PC4. The brownish ellipse marks samples of high concentrations in contaminant association D (PC4: In and Sn).

in the top area of the middle reaches in both water and surface sediments (W24 and W25 in Figure 7; S04 in Figure 8, see Figure 2 for their locations).

\subsection{Potential Pollutants and Pollution Sources}

Samples exhibiting high positive or negative scores of the four principal components are listed in Figure 9. A total of 21 elements that exhibit high correlation values with the associated principal components are evaluated against the standard high-limit concentrations prescribed by the drinking water guidelines issued 


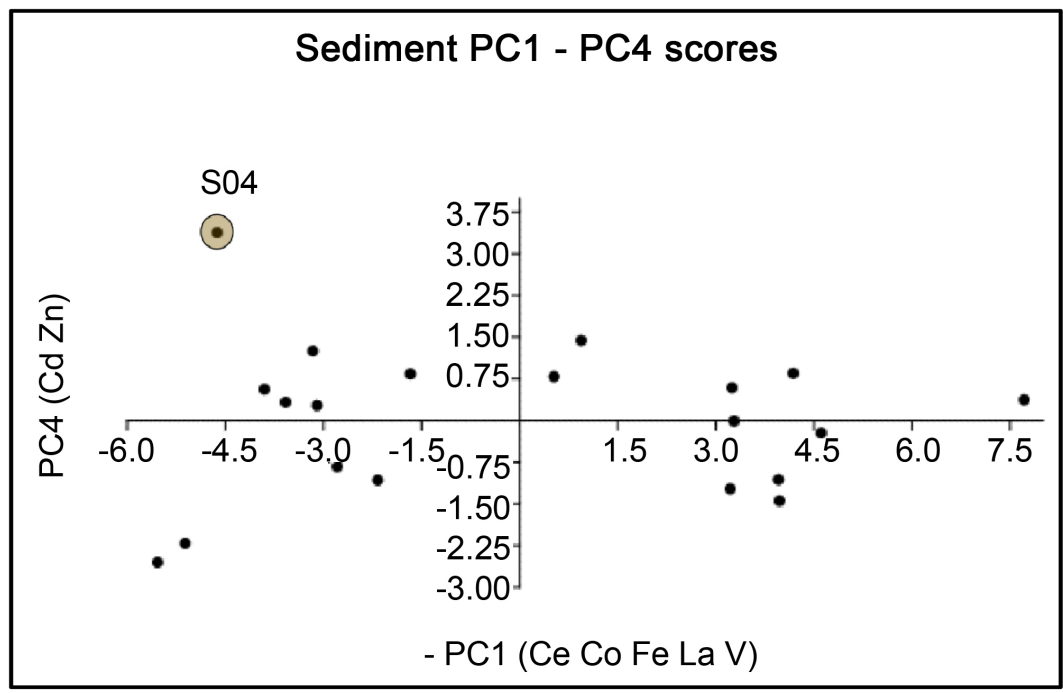

Figure 8. Scatter plot of scores of sediment samples on the plane of PC1 and PC4. The brownish circle marks sample S04 which has high concentrations in contaminant association D (PC4: Cd and Zn).

by Taiwan Environmental Protection Administration

(https://oaout.epa.gov.tw/law/EngLawContent.aspx?lan=E\&id=171\&KW=drinki ng+water). Notably only one water sample (KYR27) that has relatively high concentration of arsenic (As, $0.0148 \mathrm{mg} / \mathrm{L}$ ), slightly exceeding the prescribed standard value of water quality $(0.01 \mathrm{mg} / \mathrm{L})$, may cause minor health impact. On the other hand, quite a few samples exhibit high concentration of iron $(\mathrm{Fe})$, however, it may only cause aesthetic, cosmetic, and/or technical effects.

\section{Conclusions}

Industrial effluents, domestic sewage, and agriculture are the major anthropogenic sources of potential toxic contamination along the studied Ker-Ya River in northern Taiwan. PCA analyses of element concentrations measured from water and sediment samples recognized four element associations. The association A, mainly led by $\mathrm{Ce}, \mathrm{Co}, \mathrm{Fe}$ and La, exhibits the most dispersed distribution in water and sediments in both middle and lower reaches. The sources of these contaminants are markedly diverse geographically, and thus Glass Plant B in the low reaches of the Ker-Ya River in the downtown area of the city is not the only possible source that is responsible for their presence. The second association, comprising $\mathrm{Cu}, \mathrm{Ni}$, and other associated elements (As, $\mathrm{Hg}, \mathrm{P}, \mathrm{W}, \mathrm{Ga}$, In, and $\mathrm{Ti}$ ), appears to be contributed from industries from the upper reaches and manufacturers to the south of the Ker-Ya River, instead of the Hsinchu Science Park (HSP), a conventional target that has been blamed due to its poor practice legacy in early years. Instead, the HSP should be responsible for the presence of association D (Sn, Zn, Cd, and In) in water and sediments at the top of the middle reaches. Paper Mill A appears to be responsible for the presence of association $\mathrm{C}$ $(\mathrm{B}, \mathrm{Li}, \mathrm{Ba}$, and $\mathrm{Ca})$ in the sediment sample of the middle reaches. 


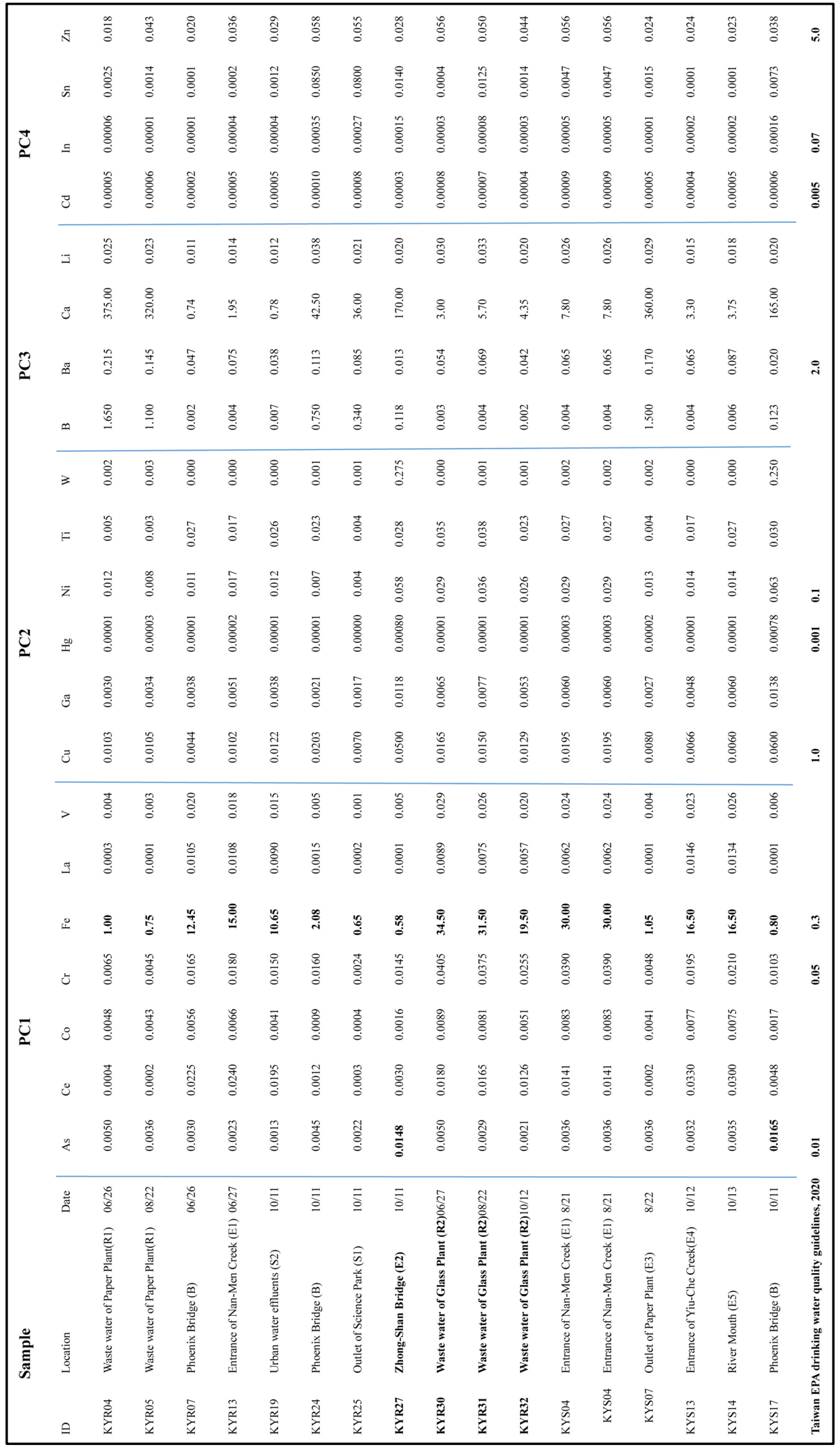

Figure 9. Element concentrations (mg/L) in samples categorized in terms of four principal components (PCs). Boldfaced numbers are those exceeding the values prescribed by Taiwan EPA drinking water guidelines (2020) https://oaout.epa.gov.tw/law/LawContent.aspx?id=FL015512. 
Although four major associations of contaminants were recognized, a close examination of the element concentrations in the water and sediments demonstrates that the Ker-Ya River is not heavily polluted, because only As in the W27 sample $(0.0148 \mathrm{mg} / \mathrm{L})$ slightly exceeded the limit value $(0.01 \mathrm{mg} / \mathrm{L})$ of drinking water quality standards issued by the Taiwan Environmental Protection Administration (TEPA). In addition, relatively high concentrations of Fe (ranging from 0.58 to $34.50 \mathrm{mg} / \mathrm{L}$ ) in all of the listed water samples in Figure 9 may cause aesthetic, cosmetic, and/or technical effects when in use, but are not considered to be seriously polluted.

\section{Funding Information}

The initial sampling and analyses were funded by the Taiwan Environmental Protection Administration (TEPA) under Project EPA-106-E3S3-02-04. Additional funding has been provided by the Featured Area Research Center Program within the framework of the Higher Education Sprout Project by the Ministry of Education, in Taiwan (Grant No. NTU-108L9010) to KYW.

\section{Availability of Data}

All of the analyzed data were taken from the report entitled "Sediment Characteristics (Rivers, Lakes, Reservoirs) Contaminants Identified Technology Development" (1/2) available from the Government Research Bulletin at https://www.grb.gov.tw/search/planDetail?id=12337429.

\section{Conflicts of Interest}

The authors declare no conflicts of interest regarding the publication of this paper.

\section{References}

[1] Islam, S., Ahmed, K., Raknuzzaman, M., Al-Mamun, H. and Islam, M.K. (2015) Heavy Metal Pollution in Surface Water and Sediment: A Preliminary Assessment of an Urban River in a Developing Country. Ecological Indicators, 48, 282-291. https://doi.org/10.1016/j.ecolind.2014.08.016

[2] Kumar, R., Rani, M., Gupta, H. and Gupta, B. (2014) Trace Metal Fractionation in Water and Sediments of an Urban River Stretch. Trace Metal Fractionation in Water and Sediments of an Urban River Stretch. Chemical Speciation and Bioavailability, 26, 200-209. https://doi.org/10.3184/095422914X14142369069568

[3] Kumar, M., Ramanathan, A.L., Tripathi, R., Farswan, S., Kumar, D. and Bhattacharya, P. (2017) A Study of Trace Element Contamination Using Multivariate 1 Statistical Techniques and Health Risk Assessment in Ground Waters of Chhaprola Industrial Area, Gautama Buddha Nagar, Uttar Pradesh, India. Chemosphere, 166, 135-145. https://doi.org/10.1016/j.chemosphere.2016.09.086

[4] Wu, Q., Zhou, H., Tam, N., Tian, Y., Tan, Y. and Zhou, S. (2016) Contamination, Toxicity and Speciation of Heavy Metals in an Industrialized Urban River: Implications for the Dispersal of Heavy Metals. Marine Pollution Bulletin, 104, 153-161. https://doi.org/10.1016/j.marpolbul.2016.01.043 
[5] Rastmanesh, F., Safaie, S. and Zarasvandi. A.R. (2018) Heavy Metal Enrichment and Ecological Risk Assessment of Surface Sediments in Khorramabad River, West Iran. Environment Monitoring and Assessment, 190, Article No. 273. https://doi.org/10.1007/s10661-018-6650-2

[6] Vu, C.T., Lin, C., Shern, C.C., Yeh, G., Le, V.G. and Tran, H.T. (2017) Contamination, Ecological Risk and Source Apportionment of Heavy Metals in Sediments and Water of a Contaminated River in Taiwan. Ecological Indicators, 82, 32-42. https://doi.org/10.1016/j.ecolind.2017.06.008

[7] Vu, C.T, Lin, C, Nguyen, K.A., Shern, C.C. and Kuo, Y.M. (2018) Ecological Risk Assessment of Heavy Metals Sampled in Sediments and Water of the Houjing River, Taiwan. Environmental Earth Sciences, 77, Article No. 388. https://doi.org/10.1007/s12665-018-7573-5

[8] Seifi, M., Mahvi, A.H., Hashemi, S.Y., Arfaeinia, H., Pasalari, H., Zarei, A. and Changani, F. (2019) Spatial Distribution, Enrichment and Geo-Accumulation of Heavy Metals in Surface Sediments near Urban and Industrial Areas in Persian Gulf. Desalination and Water Treatment, 158, 130-139.

[9] Wijesiri, B., Liu, A., He, B., Zhao, X. Ayoko, G. and Goonetilleke, A. (2019) Behaviour of Metals in an Urban River and the Pollution of Estuarine Environment. Water Research, 164, Article ID: 114911. https://doi.org/10.1016/j.watres.2019.114911

[10] Hoang, H.G., Lin, C., Tran, H.T., Chiang, C.F., Bui, X.T., Cheruiyot, N.K., Shern, C.C. and Lee, C.W. (2020) Heavy Metal Contamination Trends in Surface Water and Sediments of a River in a Highly-Industrialized Region. Environmental Technology \& Innovation, 20, Article ID: 101043. https://doi.org/10.1016/j.eti.2020.101043

[11] Yeh, G., Lin, C., Nguyen, D.H., Hoang, H.G., Shern, J.C. and Hsiao, PJ. (2021) A Five-Year Investigation of Water Quality and Heavy Metal Mass Flux of an Industrially Affected River. Environmental Science and Pollution Research. https://doi.org/10.1007/s11356-021-13149-5

[12] Chang, S., Chiu, H.M. and Tu, W. (2004) The Silence of Silicon Lambs: Speaking out Health and Environmental Impacts within Taiwan's Hsinchu Science-Based Industrial Park. IEEE International Symposium on Electronics and the Environment, 2004, Scottsdale, 10-13 May 2004, 258-263.

[13] Tu, W.L. (2005) Challenges of Environmental Governance in the Face of IT Industrial Dominance: A Study of Hsinchu Science-Based Industrial Park in Taiwan. International Journal of Environment and Sustainable Development, 4, 290-309. https://doi.org/10.1504/IJESD.2005.007742

[14] Modak, D.P., Singh, K.P., Chandra, H. and Ray, P.K. (1992) Mobile and Bound Forms of the Lower Ganges. Water Research, 26, 1541-1548. https://doi.org/10.1016/0043-1354(92)90075-F

[15] Lin, J.G., Chen, S.Y. and Su, C.R. (2003) Assessment of Sediment Toxicity by Metal Speciation in Different Particle-Size Fractions of River Sediment. Water Science and Technology, 47, 233-241. https://doi.org/10.2166/wst.2003.0694

[16] Zhang, L., Zhong, M., Xu, Y., Wang, Z. and Huang, H. (2019) The Water Quality Evaluation in Balihe Lake Based on Principal Component Analysis. Journal of Geoscience and Environment Protection, 7, 38-48. https://doi.org/10.4236/gep.2019.78003

[17] Kim, B.S.M., Angeli, J.L.F., Ferreira, P.A.L., Sartoretto, J.R., Miyoshi, C., Mahiques, M.M. and Figueira, R.C.L. (2017) Use of a Chemometric Tool to Establish the Re- 
gional Background and Assess Trace Metal Enrichment at Baixada Santista-Southeastern Brazil. Chemosphere, 166, 372-379. https://doi.org/10.1016/j.chemosphere.2016.09.132

[18] Reidy, L., Bu, K., Godfrey, M. and Cizdziel, J.V. (2013) Elemental Fingerprinting of Soils Using ICP-MS and Multivariate Statistics: A Study for and by Forensic Chemistry Majors. Forensic Science International, 233, 37-44.

https://doi.org/10.1016/j.forsciint.2013.08.019

[19] Rezaali, M., Karimi, A., Yekta, N.M. and Fard, R.F. (2019) Identification of Temporal and Spatial Patterns of River Water Quality Parameters Using NLPCA and Multivariate Statistical Techniques. International Journal of Environmental Science and Technology, 17, 2977-2994. https://doi.org/10.1007/s13762-019-02572-4

[20] Wang, J., Gao, B., Yin, S., Liu, L., Xu, D. and Li, Y., (2019) Comprehensive Evaluation and Source Apportionment of Potential Toxic Elements in Soils and Sediments of Guishui River, Beijing. Water2019, 11, Article No. 1847.

https://doi.org/10.3390/w11091847

[21] Zhang, Y., Guo, F., Meng, W. and Wang, X.Q. (2009) Water Quality Assessment and Source Identification of Daliao River Basin Using Multivariate Statistical Method. Environmental Monitoring and Assessment, 152, Article No. 105.

https://doi.org/10.1007/s10661-008-0300-Z

[22] Ustaoğlu, F. and Islam, S. (2020) Potential Toxic Elements in Sediment of Some Rivers at Giresun, Northeast Turkey: A Preliminary Assessment for Ecotoxicological Status and Health Risk. Ecological Indicators, 113, Article ID: 106237. https://doi.org/10.1016/j.ecolind.2020.106237

[23] Hammer, Ø., Harper, D.A.T. and Ryan, P.D. (2001) Past: Paleontological Statistics Software Package for Education and Data Analysis. Palaeontologia Electronica, 4, $1-9$. 